\title{
CORRIGENDUM
}

\section{Chemical modulation of chaperone-mediated autophagy by retinoic acid derivatives}

Jaime Anguiano, Thomas P Garner, Murugesan Mahalingam, Bhaskar C Das, Evripidis Gavathiotis \& Ana Maria Cuervo

Nat. Chem. Biol. 9, 374-382 (2013); published online 14 April 2013; corrected after print 28 June 2013

In the version of this article initially published, one of the three gray bars in Figure 6a was not defined, and the asterisks for these bars were misaligned. The errors have been corrected in the HTML and PDF versions of the article.

\section{ERRATUM}

\section{Insights into mucopolysaccharidosis I from the structure and action of $\alpha$-L-iduronidase}

Haiying Bie, Jiang Yin, Xu He, Allison R Kermode, Ethan D Goddard-Borger, Stephen G Withers \& Michael N G James

Nat. Chem. Biol.; doi:10.1038/nchembio.1357; corrected online 20 September 2013

In the version of this article initially published online, in the methods section "Synthesized IDUA inhibitors," two different chemical names were provided for 5F-IdoAF, and a complete name for $2 \mathrm{~F}$-IdoAF was inadvertently omitted. Additionally, in the legend for Figure 5 , one instance of $\mathrm{mg}^{-1}$ was mistakenly written as $\mathrm{mg}^{-}$. The page numbers for reference 6 were also incorrect. These errors have been corrected for the print, PDF and HTML versions of this article.

\section{CORRIGENDUM}

\section{Immunology: Cytosolic DNA sensing unraveled}

Daniel Panne

Nat. Chem. Biol. 9, 533-534 (2013); published online 19 August 2013; corrected after print 25 September 2013

In the version of this article initially published, the sentence "Three papers now report that cGAS produces a new type of second messenger molecule ${ }^{1,4,5}$ " did not also attribute the finding to reference 6 . The error has been corrected in the HTML and PDF versions of the article. 